\title{
Dermacentor reticulatus, a putative vector of Babesia cf. microti (syn. Theileria annae) piroplasm
}

\author{
Adnan Hodžić $^{1}$ • Johanna Zörer ${ }^{1}$ • Georg Gerhard Duscher ${ }^{1}$
}

Received: 12 January 2017 / Accepted: 16 January 2017 / Published online: 23 January 2017

(C) The Author(s) 2017. This article is published with open access at Springerlink.com

\begin{abstract}
Babesia cf. microti (syn. Theileria annae, Babesia microti-like, Babesia vulpes) is a recently recognized tickborne piroplasm that infects domestic and wild carnivores. Although Ixodes hexagonus is considered as the leading candidate responsible for the transmission, its capacity to act as a competent vector has not yet been confirmed. This study reports the occurrence of B.cf. microti in unfed Dermacentor reticulatus for the first time, suggesting that this tick species may be implicated in the life cycle of this canine parasite. Out of 128 questing D. reticulatus ticks collected in eastern Austria, nine (7\%) and four (3\%) of them were found to be PCR positive for $B$. canis and B. cf. microti, respectively. Although the data presented here are not sufficient to explicitly state that $D$. reticulatus is a competent vector of $B$. cf. microti, our results can at least give a hint for future studies, which need to include experimental transmission in order to confirm its vector competence and possible involvement in the transmission of this babesial species.
\end{abstract}

Keywords Babesia cf. microti - Theileria annae .

Dermacentor reticulatus $\cdot$ Potential vector $\cdot$ PCR $\cdot$ Sequencing

\section{Introduction}

Babesia cf. microti is a protozoan tick-transmitted parasite affecting domestic dogs and wild carnivores worldwide

Georg Gerhard Duscher

georg.duscher@vetmeduni.ac.at

1 Institute of Parasitology, Department of Pathobiology, University of Veterinary Medicine Vienna, Veterinaerplatz 1, 1210 Vienna, Austria
(Alvarado-Rybak et al. 2016). It is also known as Theileria (Babesia) annae, Babesia sp. "Spanish dog isolate" and Babesia vulpes, but due to lack of an appropriate description, all these names are considered unavailable (Harris 2016). Thus, given that this canine piroplasm is genetically most closely related to zoonotic $B$. microti and that current valid name is not yet available, it can only be informally referred as "microti group" (Harris 2016). Infection by B. cf. microti in dogs can cause severe disease with clinical signs of hemolytic regenerative anemia, thrombocytopenia, azotemia, anorexia, lethargy, renal failure, or even death (Zahler et al. 2000; Falkenö et al. 2013; Miró et al. 2015), while clinical impact of the parasite in wild carnivores still remains abstruse (Clancey et al. 2010; Miró et al. 2015).

The vector of $B$. cf. microti is currently unknown, but hedgehog tick Ixodes hexagonus has been proposed as the main candidate responsible for its transmission, based solely on the associations between the occurrence of this tick species and infection in dogs (Camacho et al. 2003). However, the detection of $B$. cf. microti in domestic and wild canids originating from areas lacking $I$. hexagonus (Birkenheuer et al. 2010; Falkenö et al. 2013) may indicate the possible involvement of other ixodid ticks in the transmission cycle of this protozoon. Nevertheless, the piroplasmid DNA has been detected in engorged I. ricinus, I. canisuga, I. hexagonus, and Rhipicephalus sanguineus ticks collected from different animals (Iori et al. 2010; Lledó et al. 2010; Najm et al. 2014). However, their competence to serve as vectors of $B$. cf. microti has not been proven, and the DNA present in the ticks may be a result of the current blood meal (Najm et al. 2014). As in case of other canine babesial species, i.e., B. canis and $B$. gibsoni, the non-vectorial routes of transmission including transplacental transmission and direct infection by dog bite can also occur in B. cf. microti (Yeagley et al. 2009; Simões et al. 2011). 
In this study, we report the detection of $B$. cf. microti piroplasm in unfed adults of $D$. reticulatus collected in eastern Austria and also discuss its potential role as vector of this little known parasite.

\section{Material and methods}

In March, April, and September 2016, questing D. reticulatus ticks were collected from several suitable locations in Burgenland, eastern Austria by flagging vegetation (Fig. 1). After the morphological identification, all specimens were processed individually for DNA extraction following the procedure previously described (Hodžić et al. 2016). The quality of tick DNA was assessed by PCR amplification of the tick mitochondrial 16S ribosomal ribonucleic acid (rRNA) gene (Halos et al. 2004). For molecular detection and characterization of Babesia and Theileria species, two sets of primers were used to amplify 561-bp-long fragment of $18 \mathrm{~S}$ rRNA gene in nested PCR reaction (Zintl et al. 2011). Amplified PCR products were visualized by agarose gel electrophoresis, purified, and sequenced in both directions (Mycrosinth, Austria). The sequences were aligned and compared for similarity with those available in GenBank ${ }^{\circledR}$ database using Basic Local Alignment Search Tool (BLAST) analysis.

\section{Results and discussion}

Out of total 128 adult specimens of $D$. reticulatus collected, 13 (10\%) were found to be positive with Babesia/Theileria specific nested PCR. Sequence analysis and BLAST search of nine samples $(7 \%)$ revealed $100 \%$ identity to the sequences of $B$. canis found in unfed adult of D. reticulatus (GenBank ${ }^{\circledR}$ accession no. AY649326) and domestic dogs (e.g., KT008057). The remaining four sequences (3\%) were $100 \%$ identical to $B$. cf. microti previously identified in foxes from Austria (KM115972, KM115968), Bosnia and Herzegovina (KP216411), Great Britain (KT580785), and foxes (KT223483) and dogs (e.g., EU583387, AY457974) from endemic regions in Spain. The nucleotide sequences herein obtained have been deposited in GenBank ${ }^{\circledR}$ database and are available under accession numbers KY447296 (B. canis) and KY447297 (B. cf. microti).

To the best of our knowledge, this is the first report of $B$. cf. microti piroplasm in unfed adults of $D$. reticulatus. Although the ticks could acquire the parasite at the nymphal stage by feeding on an infected animal host as already implied for Hepatozoon canis (Giannelli et al. 2013), it is not unreasonable to propose this tick species as a potential vector of $B$. cf. microti. First of all, D. reticulatus is considered as an ideal arthropod vector due to its extraordinary biological features, such as high reproduction rate, rapid development cycle, ability to survive in different environments, and capacity to host
Fig. 1 Sampling area and sites with negative, Babesia canis and Babesia cf. microti positive Dermacentor reticulatus. The size of the circles is proportional to the number of ticks sampled

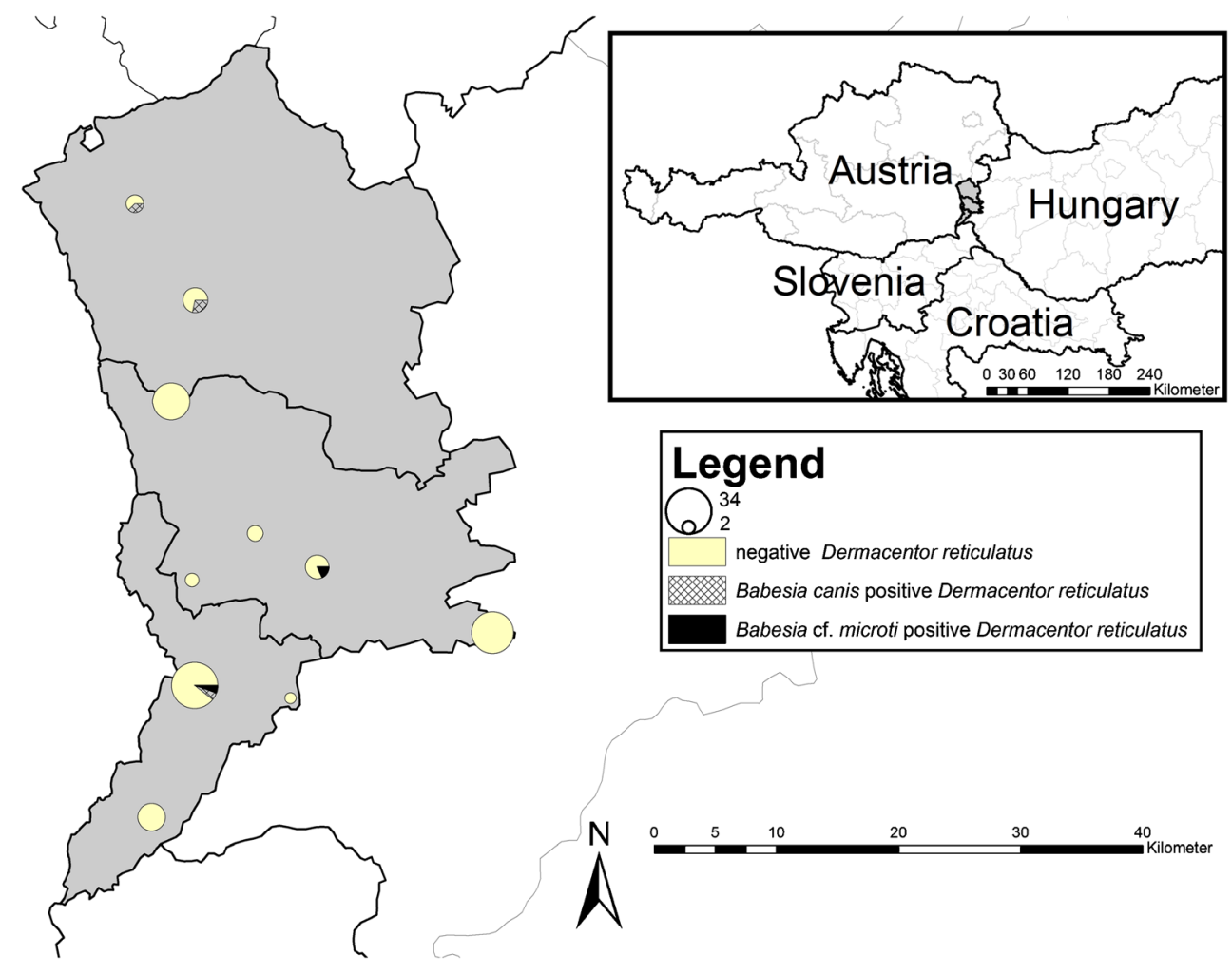


and transmit a wide range of pathogens of medical and veterinary concern, including Babesia and Theileria species of canids and equids (Földvári et al. 2016). Furthermore, it has recently been suggested as vector of closely related B. microti in Europe (Wójcik-Fatla et al. 2012). In addition, $D$. reticulatus is one of the most reported tick species in Europe (Földvári et al. 2016), and among other, it feeds on domestic and wild carnivores (e.g., dogs, foxes, wolves) that serve as hosts for $B$. cf. microti pathogen. Also, it was the most common tick after $I$. hexagonus found in $\operatorname{dogs}$ infected by $B$. cf. microti in hyperendemic region in northwestern Spain (Camacho et al. 2003). Last but not least, the fact that the geographical distribution of $D$. reticulatus in Europe closely overlaps with the distribution of $B$. cf. microti (see AlvaradoRybak et al. 2016; Földvári et al. 2016), as well as that the same sequence type identified in host-seeking $D$. reticulatus ticks is also circulating among vertebrate hosts, supports the existence of the possible tick-host-pathogen association. Recently, we identified $50 \%$ of the foxes to harbor this pathogen in a close by area little further north (Duscher et al. 2014), emphasizing the occurrence in wildlife consequently bearing a potential impact on domestic dogs.

In the present study, $B$. cf. microti DNA was detected in unfed $D$. reticulatus ticks, suggesting that this tick species might be a competent vector for this canine piroplasm. Although the data presented here are not sufficient to explicitly support this hypothesis, our results can at least give a hint for future studies which need to include experimental transmission in order to confirm its vector competence and implication in the transmission of $B$. cf. microti.

Acknowledgements Open access funding provided by University of Veterinary Medicine Vienna. We would like to thank Walpurga WillePiazzai (Institute of Parasitology, University of Veterinary Medicine Vienna, Austria) for her technical assistance. This study was conducted under the frame of EurNegVec COST Action TD1303.

Open Access This article is distributed under the terms of the Creative Commons Attribution 4.0 International License (http:// creativecommons.org/licenses/by/4.0/), which permits unrestricted use, distribution, and reproduction in any medium, provided you give appropriate credit to the original author(s) and the source, provide a link to the Creative Commons license, and indicate if changes were made.

\section{References}

Alvarado-Rybak M, Solano-Gallego L, Millán J (2016) A review of piroplasmid infections in wild carnivores worldwide: importance for domestic animal health and wildlife conservation. Parasit Vectors 9:538

Birkenheuer AJ, Horney B, Bailey M, Scott M, Sherbert B, Catto V, Marr HS, Camacho AT, Ballman AE (2010) Babesia microti-like infections are prevalent in north American foxes. Vet Parasitol 172:179-182

Camacho AT, Pallas E, Gestal JJ, Guitián FJ, Olmeda AS, Telford SR, Spielman A (2003) Ixodes hexagonus is the main candidate as vector of Theileria annae in northwest Spain. Vet Parasitol 112:157163

Clancey N, Horney B, Burton S, Birkenheuer A, McBurney S, Tefft K (2010) Babesia (Theileria) annae in a red fox (Vulpes vulpes) from Prince Edward Island, Canada. J Wildl Dis 46:615-621

Duscher GG, Fuehrer H-P, Kübber-Heiss A (2014) Fox on the runmolecular surveillance of fox blood and tissue for the occurrence of tick-borne pathogens in Austria. Parasites Vectors 7:521

Falkenö U, Tasker S, Osterman-Lind E, Tvedten HW (2013) Theileria annae in a young Swedish dog. Acta Vet Scand 55:50

Földvári G, Široký P, Szekeres S, Majoros G, Sprong H (2016) Dermacentor reticulatus: a vector on the rise. Parasit Vectors 9:314

Giannelli A, Ramos RA, Di Paola G, Mencke N, Dantas-Torres F, Baneth G, Otranto D (2013) Transstadial transmission of Hepatozoon canis from larvae to nymphs of Rhipicephalus sanguineus. Vet Parasitol 196:1-5

Halos L, Jamal T, Vial L, Maillard R, Suau A, Le Menach A, Boulouis HJ, Vayssier-Taussat M (2004) Determination of an efficient and reliable method for DNA extraction from ticks. Vet Res 35:709-713

Harris JD (2016) Naming no names: comments on the taxonomy of small piroplasmids in canids. Parasit Vectors 9:289

Hodžić A, Fuehrer HP, Duscher GG (2016) First molecular evidence of zoonotic bacteria in ticks in Bosnia and Herzegovina. Transbound Emerg Dis doi. doi:10.1111/tbed.12473

Iori A, Gabrielli S, Calderini P, Moretti A, Pietrobelli M, Tampieri MP, Galuppi R, Cancrini G (2010) Tick reservoirs for piroplasms in central and northern Italy. Vet Parasitol 170:291-296

Lledó L, Giménez-Pardo C, Domínguez-Peñafiel G, Sousa R, Gegúndez MI, Casado N, Criado A (2010) Molecular detection of hemoprotozoa and Rickettsia species in arthropods collected from wild animals in the Burgos Province, Spain. Vector Borne Zoonotic Dis 10:735-738

Miró G, Checa R, Paparini A, Ortega N, González-Fraga JL, Gofton A, Bartolomé A, Montoya A, Gálvez R, Mayo PP, Irwin P (2015) Theileria annae (syn. Babesia microti-like) infection in dogs in NW Spain detected using direct and indirect diagnostic techniques: clinical report of 75 cases. Parasit Vectors 8:217

Najm NA, Meyer-Kayser E, Hoffmann L, Herb I, Fensterer V, Pfister K, Silaghi C (2014) A molecular survey of Babesia spp. and Theileria spp. in red foxes (Vulpes vulpes) and their ticks from Thuringia, Germany. Ticks Tick Borne Dis 5:386-391

Simões PB, Cardoso L, Araújo M, Yisaschar-Mekuzas Y, Baneth G (2011) Babesiosis due to the canine Babesia microti-like small piroplasm in dogs - first report from Portugal and possible vertical transmission. Parasit Vectors 4:50

Wójcik-Fatla A, Bartosik K, Buczek A, Dutkiewicz J (2012) Babesia microti in adult Dermacentor reticulatus ticks from eastern Poland. Vector-Borne Zoonotic Dis 12:841-843

Yeagley TJ, Reichard MV, Hempstead JE, Allen KE, Parsons LM, White MA, Little SE, Meinkoth JH (2009) Detection of Babesia gibsoni and the canine small Babesia "Spanish isolate" in blood samples obtained from dogs confiscated from dogfighting operations. J Am Vet Med Assoc 235:535-539

Zahler M, Rinder H, Schein E, Gothe R (2000) Detection of a new pathogenic Babesia microti-like species in dogs. Vet Parasitol 89: 241-248

Zintl A, Finnerty EJ, Murphy TM, de Waal T, Gray JS (2011) Babesias of red deer (Cervus elaphus) in Ireland. Vet Res 42:7 